\title{
THE LATE IRON AGE BRONZE HELMET FROM APAHIDA (TRANSYLVANIA) ${ }^{1}$
}

RUSTOIU, Aurel - BERECKI, Sándor. Bronzová prilba z neskorej doby železnej z Apahidy (Transylvánia). Bronzová prilba objavená v laténskom hrobe v Apahide v roku 1900 je dobre známa v odbornej literatúre. Nález sa dlhodobo nachádzal v súkromnej zbierke. Len nedávno bol darovaný do krajského múzea v Târgu Mureş. Pri tejto príležitosti boli identifikované zatial' nepublikované fragmenty, ktoré umožňujú dôkladnejšiu typologickú identifikáciu. Prilba z Apahidy opätovne otvára debatu o typológii a chronológii analogických nálezov z Karpatskej kotliny a umožňuje detailnejší pohl'ad na elitu rurálnych komunít v sledovanom regióne v období včasnej a strednej doby laténskej. Prilby so zosilnenou kalotou sa dajú zaradit’ do dvoch variantov: batinský variant predstavujú prilby, ktoré majú samostatne pripevnený chránič krku (ako prilba z Apahidy). Ochridský variant reprezentujú prilby, ktoré majú kalotu a chránič krku kovaný z jedného plechu. Technika výroby jednotlivých variantov, ako aj ich rozšírenie a datovanie ponúkajú relevantné informácie o ich pôvode. Prvý variant bol vytvorený remeselníkmi z Karpatskej kotliny, druhý variant vyrobili na Balkáne s pomocou talianskych kováčov. Prilby patriace k jednotlivým variantom sa stali dôležitými vizuálnymi prejavmi sociálneho postavenia ich majitel'ov.

Kl'účové slová: prilba, neskorá doba železná, Karpatská kotlina, Balkán, Kelti

Keywords: helmet, Late Iron Age, Carpathian Basin, Balkans, Celts

\section{Introduction}

At the turn of the $20^{\text {th }}$ century, when scientific archaeology was only beginning in Transylvania, antiquarians and amateur archaeologists still played an important role in recovering ancient remains and the related information which were later useful for professional archaeological research. Many had an academic education, especially in humanities or natural sciences. The archaeological collections which were born out of their passion for the past enriched later the collections of various museums (see, for example, Bajusz 2005; Ferencz 2017). This is the case of the private collection assembled by Endre Orosz, a teacher from Apahida, a locality which is now known for the funerary discoveries belonging to different periods, among other things. Still, this collection had a rather complicated history; only very recently his descendants donated the last remains to the Târgu Mureş Museum. The careful initial registration of this collection contributed to the identification of some artefacts which are already known from specialist literature, and also to the "rediscovery" of some previously unknown items. Among the latter are some fragments of a La Tène bronze helmet coming from the Apahida cemetery, still unpublished. These fragments provide an opportunity to resume the debate regarding the typology and chronology of similar pieces from the Carpathian Basin, leading to a series of observations regarding the Early and Middle LT elites of the rural communities from the region in question. Both the problems regarding

\footnotetext{
This work was supported by a grant of the Ministry of Research and Innovation, CNCS - UEFISCDI, project number PN-III-P4-ID-PCE-2016-0353, within PNCDI III, and also by the János Bolyai Research Scholarship of the Hungarian Academy of Sciences granted to S. Berecki.
} 
the La Tène chronology in the Carpathian Basin and the analysis of a wide range of artefacts associated with different social groups from this region were thoroughly pursued by Jozef Bujna during the last decades (see, for example, Bujna 1982). Accordingly, the topic of this article represents a well-deserved homage for his fruitful scientific activity. [A.R. - S. B.]

\section{The context of discovery}

The antiquarian and amateur archaeologist E. Orosz (1871 - 1945) worked as a teacher for 25 years in Apahida, near Cluj-Napoca, in Transylvania. His archaeological and historical collection - which was largely lost through time - consisted of different artefacts dated to a very wide period of time between the Neolithic and the modern times. Some of the artefacts were acquired while many others were discovered by E. Orosz during field surveys or archaeological excavations. From his notes it is known that in 1913 his collection included 25000 artefacts, of which 1200 were coins (these were lost after his death). The majority of these artefacts came from the surroundings of Cluj, the Somes valley and the Transylvanian plain, but there were also items found on sites from the Mureş valley (Aiud, Vințu de Jos, etc), Banat (Novi Bečej, Checea) or the Great Hungarian Plain (Tószeg) (Berecki 2017).

The prehistoric and Roman provincial site at Apahida-Râtul Satului was discovered by E. Orosz in 1896, while first graves belonging to the Late Iron Age were identified in the spring of 1900 during gravel quarrying (Orosz 1908, 172, 173). Archaeological excavations were later carried out in the same location. E. Orosz coordinated these excavations in $24^{\text {th }}$ October $6^{\text {th }}$ November 1900 (Vincze 2014, 388), while between $6^{\text {th }}$ November and $21^{\text {st }}$ November these were taken over by the student I. Kovács, who unearthed 21 graves belonging to the Late Iron Age (Berecki 2015, 107; Kovács 1911; Vincze 2014, 139). After the end of Kovács' investigations, in the spring and autumn of 1901 and in the following years E. Orosz collected archaeological artefacts from the area of the La Tène cemetery (Orosz 1908, 173).

One interesting group of artefacts was found in $27^{\text {th }}$ March 1900. The reconstruction of the inventory is difficult due to the manner in which E. Orosz recovered the artefacts from the La Tène cemetery and the subsequent history of his collection. Still, the drawings made by E. Orosz are very helpful because he included not only descriptions and dimensions, but also the date of discovery; other useful data come from the labels attached to some of the recovered objects.

After the death of E. Orosz in 1945, the collection remained in the family's possession. The LT artefacts were studied in 1947 - 1948 by V. Zirra, who only published the cemetery three decades later (Zirra 1976). According to the written request from $8^{\text {th }}$ November 1948 of the National Museum of Antiquities, signed by I. Nistor (document preserved in the Orosz Endre archive from the Mureş County Museum in Târgu Mureş), some artefacts from the Late Iron Age cemetery and E. Orosz's film negatives were taken to Bucharest to be studied by V. Zirra. Some of the finds and drawings could have disappeared on that occasion. In an article about the Celtic cemetery at Apahida, which was published in 1971, I. H. Crişan mentions that the archaeological evidence was preserved in the History Museum in Cluj, alongside those coming from the excavations of I. Kovács (Crişan 1971, 37, n. 3). In 1973, a large part of these items were returned to the descendants of E. Orosz; the preserved artefacts and documentation were donated in 2015 by his nieces to the Mureş County Museum in Târgu Mureş (Berecki 2017, 105).

M. Rusu provided the first inventory of the finds and drawings of the preserved fragments of the helmet on the basis of a note written by E. Orosz, now lost. Thus the grave contained one urn, another vessel containing burnt bones, a sword, three spear heads, a helmet and horse bones (Rusu 1969, 291, n. 29, fig. 10; see also Rusu/Bandula 1970, 36, 37, n. 45, pl. 17). It seems that it was a cremation burial with the remains placed in an urn, a funerary rite which is quite rarely attested inside the Carpathians range (Berecki 2006). /152/

I. H. Crişan considered that E. Orosz actually discovered two graves. One of them, 


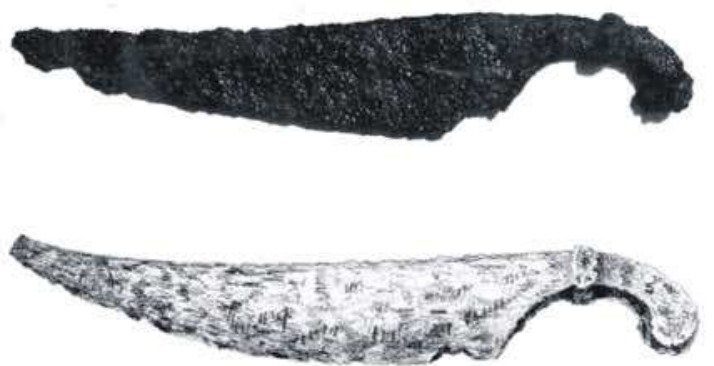

1

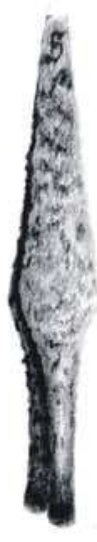

2
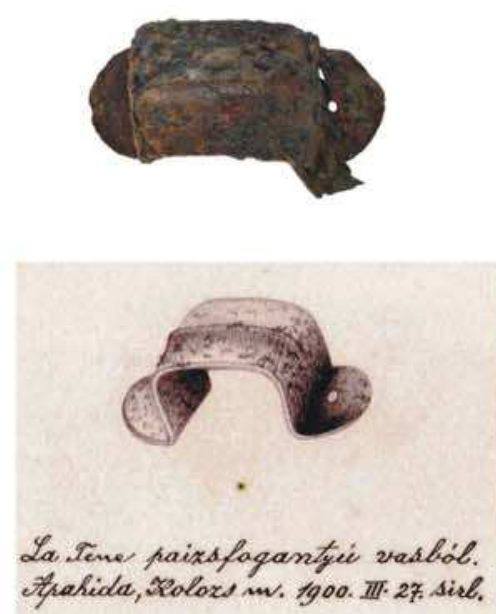

3

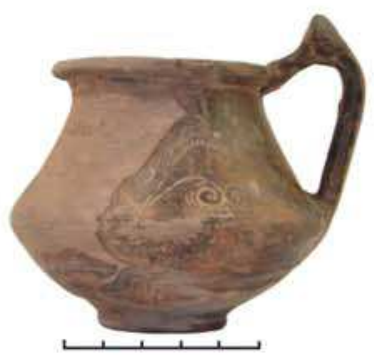

4

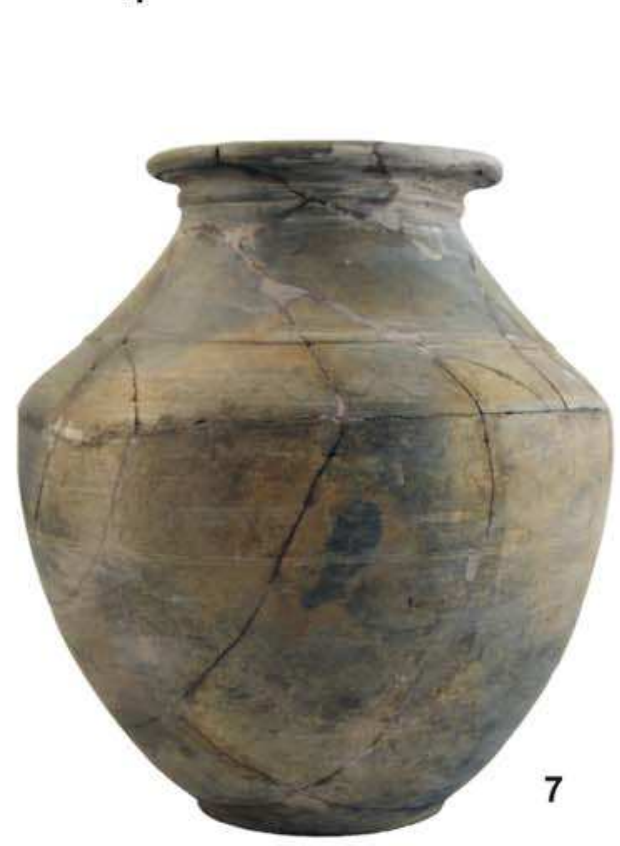

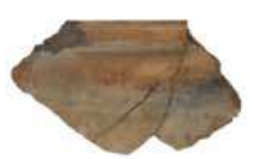

5

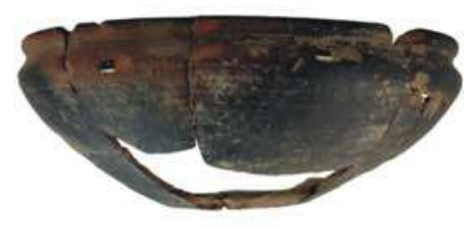

6

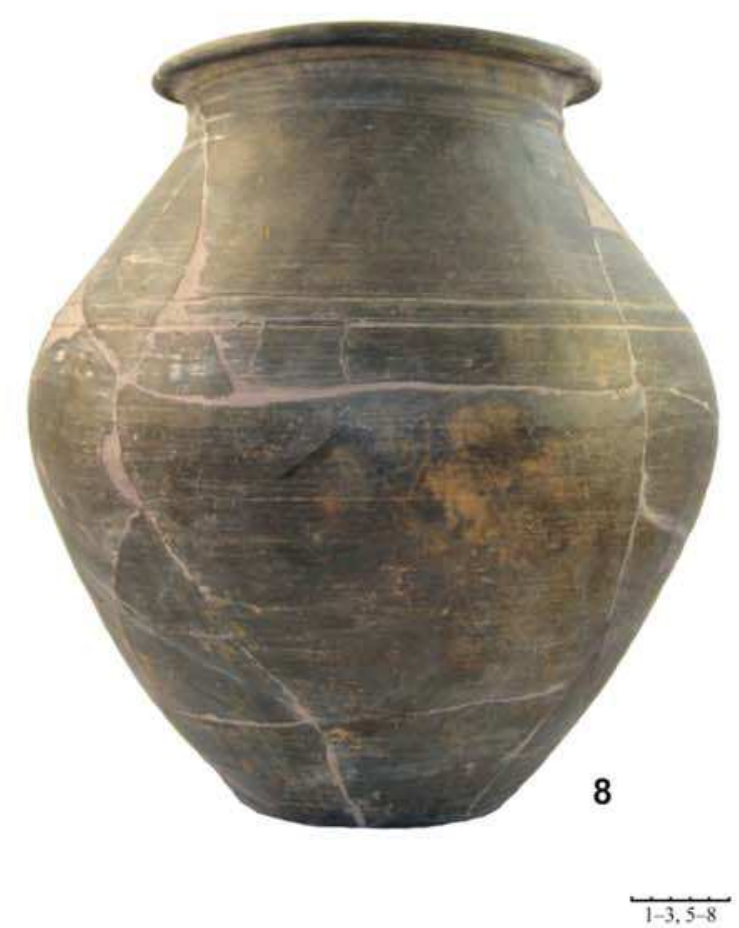

Fig. 1. Apahida, the inventory of the grave discovered in $27^{\text {th }}$ March 1900. 1 - Iron knife (photo and drawing from Orosz archive); 2 - Iron spear heads (drawings from Orosz archive); 3 - Shield boss (photo S. Berecki and drawing from Orosz archive); 4-8 - Ceramic vessels. Photo by S. Berecki 
ascribed to a chieftain, contained the helmet, a sword, one knife, three spears, one bronze ring, one beaker and one large vessel. Only the fragments of helmet, one vessel and the two fused spear heads were still preserved at that date, whereas the human and animal bones were not mentioned. Two other vessels, which were apparently discovered in the same day, presumably came from another grave (Crişan 1971, 39, Pl. 5: 1, 4, 7; 12; 13; 14: 12).

Unlike I. H. Crişan, V. Zirra considered that all of the discoveries from 27 March 1900 were part of a single funerary inventory. He also mentioned the note of E. Orosz, which is said to have been glued to the helmet, but failed to mention the human bones deposited in the vessel and the horse bones (Zirra 1976, 144).

On the basis of available information, the note mentioned by all of the authors dealing with the grave until the 1970s, and the drawings preserved in Orosz archive, in 27 March 1900 the following artefacts were discovered: one bronze helmet with gilded decoration (fig. 2); one sword which is now lost, being only mentioned in the note; one knife which is illustrated in Orosz archive and then only by V. Zirra, now lost (fig. 1: 1); three spears, all lost, although two were still existing in the 1970s, while the third was mentioned in the note (fig. 1: 2); one shield boss (152 $\times 64 \mathrm{~mm}, 55 \mathrm{~mm}$ thick) with a fused bronze fragment of the helmet's calotte (fig. 1: 3); one bronze ring, only mentioned in the note, now lost; one decorated ceramic beaker (fig. 1: 4; 7: 1); the fragmentary rim of a ceramic bowl (fig. 1: 5); one ceramic bowl (fig. 1: 6); two large ceramic vessels (fig. 1: 7, 8). All ceramic vessels were wheel-made (Hunyadi 1942, Pl. 74: 7; 84: 7; Berecki et al. 2017, Cat. no. 190, 196, 203, 207, 210, 224, 226, 333, 336, 337, 341; Crişan 1971, Pl. 5: 1, 4, 7; 6: 1-3, 12, 13; 14: 12; Rusu 1969, fig. 10; Rusu/Bandula 1970, 36, 37, Pl. 17; Zirra 1976, 142-144, fig. 11). The second wheel-made beaker (fig. 7: 2), mentioned by V. Zirra and now lost, was actually discovered later, in 15 May 1900, according to Orosz's notes (Zirra 1976, fig. 11: 7; see also Hunyadi 1942, Pl. 73: 10).

The helmet, which will be fully analysed below, was first mentioned in 1901 in a short note published in Archaeologiai Értesító from Budapest, more likely on the basis of the informal observations provided by Orosz (fig. 2: 1). The note lists different artefacts recovered from the cemetery, including a gold foil and a bronze helmet (ArchÉrt 1901, 288). In subsequent articles by M. Rusu, I. H. Crişan and V. Zirra the illustrations are showing different details while also documenting the preservation state of the artefact. For example, the first article includes a drawing of three fragments of the helmet, while I. H. Crişan's article shows the decorated calotte with a missing fragment, but includes another part of the calotte among the drawings and one fragment on the plate containing photographs of the artefact (fig. 2: 2). Lastly, the article of V. Zirra only shows the two decorated fragments with studs. On the other hand, the neck guard is missing from all of these publications even if the artefact was still preserved in the Orosz collection (fig. 2: 3-5; 3: 1-4). Another element which was lost, being only known from the original drawing of the discoverer, is the second triangular plaque which was attached to the calotte.

Both the older illustrations and the still unpublished fragments from the Orosz collection provide an opportunity to resume the debate regarding the manufacturing technique, while bringing into discussion some typological and chronological details. Another aspect that is worth taking into consideration concerns the significance of this artefact in the context of the eastern Celtic world. [S.B.]

\section{The helmet from Apahida - technical details}

Although some parts of the helmet are missing, their published drawings and the recently identified fragments allow the reconstruction of the entire artefact.

The helmet was made of several elements. The hemispherical calotte and the neck guard were mould cast and then hammered to obtain the required shape. The triangular plaques attached to the calotte and the cheek-pieces, which are now lost, were perhaps made in the same manner. The XRF analysis made by Assoc. Prof. Dr. Simona Varvara from " 1 Decembrie /154/ 

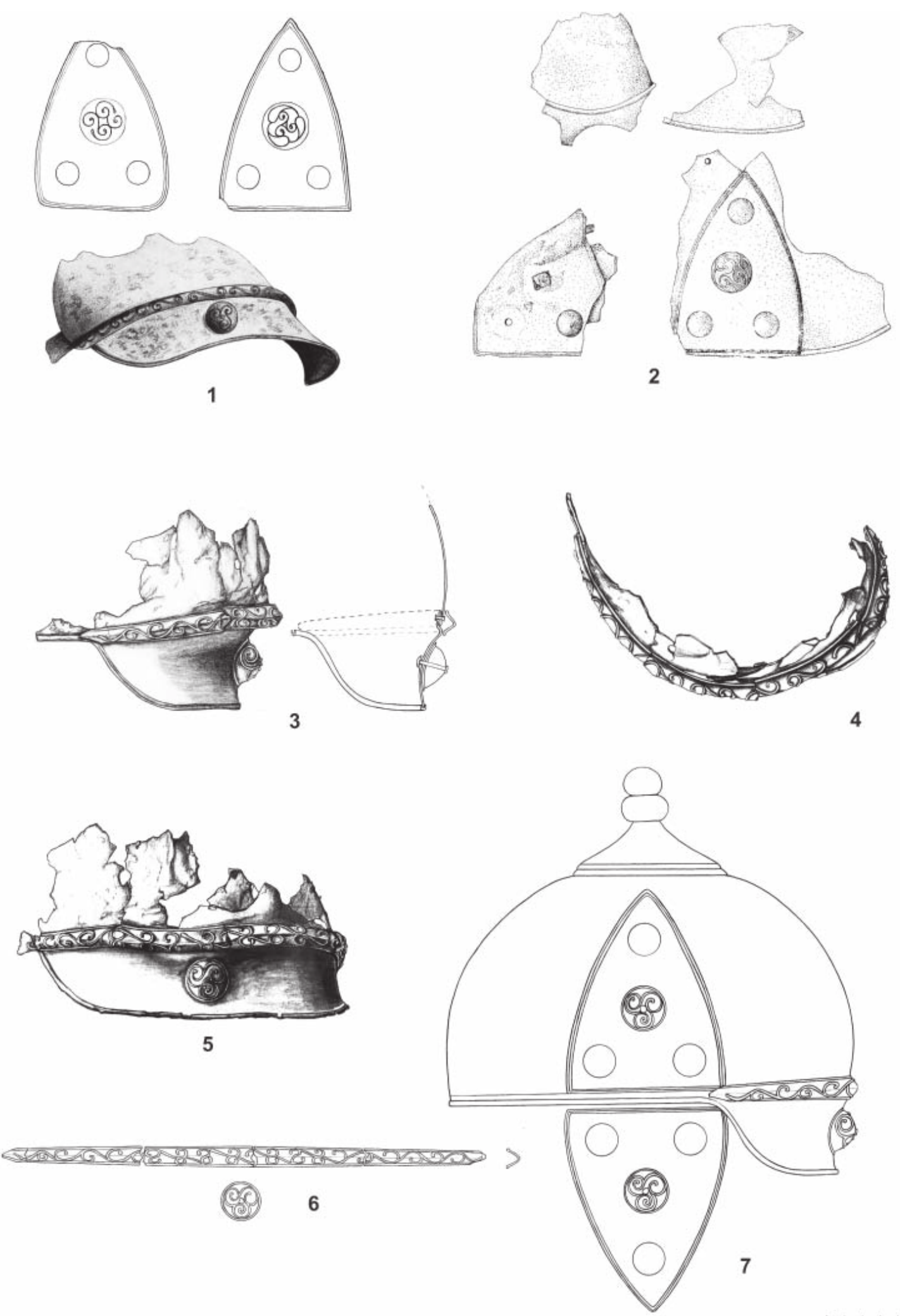

Fig. 2. Apahida, the bronze helmet. 1 - Drawings from Orosz archive; 2 - The missing fragments of the helmet (after Crişan 1971); 3-7 - Preserved fragments and ideal helmet's reconstruction.

Drawings by N. Şugar 
1918" University of Alba Iulia, Dept. of Exact Sciences and Environmental Engineering of the fragments from the helmet's calotte (Table 1) has shown that the metal used for the calotte is an alloy of copper $(80.57 \%)$ and tin $(11.63 \%)$. The resulting bronze sheet was suitable for hammering; a similar type of alloy was used, for example, to manufacture some Bronze Age helmets discovered in the Carpathian Basin (Mödlinger et al. 2013). The same analysis revealed traces of other chemical elements, like $\mathrm{Fe}, \mathrm{Si}, \mathrm{Ca}, \mathrm{Al}, \mathrm{Cl}$ etc, which could have resulted from the soil in which the helmet was buried. Other trace elements, like As, Sb, and Ag, were identified on the calotte's oxidized surface; in the case of the aforementioned Bronze Age helmets, it was observed that "such elements show a lower ionic diffusivity in the copper based oxide matrix as is the case of tin. Therefore, whenever these elements are present as minor or trace elements in the alloy, they concentrate in the oxidised patina" (Mödlinger et al. 2013, 27).

Table 1. XRF analysis of the fragments of calotte. Author: Simona Varvara.

\begin{tabular}{|c|c|c|c|c|c|c|c|c|c|c|c|c|c|c|c|c|c|c|}
\hline El & $\mathrm{Cu}$ & Sn & $\mathbf{F e}$ & Si & $\mathrm{Ca}$ & As & Al & $\mathrm{Cl}$ & $\mathbf{P x}$ & Co & $\mathrm{Ni}$ & $\mathbf{Z n}$ & $\mathbf{w}$ & $\mathrm{Pb}$ & Sb & Ag & Ga & Mo \\
\hline $\mathrm{m} / \mathrm{m} \%$ & 80.57 & 11.63 & 3.53 & 2.02 & 0.78 & 0.309 & 0.286 & 0.203 & 0.127 & 0.125 & 0.115 & 0.083 & 0.078 & 0.0614 & 0.03 & 0.0223 & 0.0124 & 0.0077 \\
\hline StdErr & 0.2 & 0.16 & 0.09 & 0.07 & 0.2 & 0.015 & 0.096 & 0.025 & 0.048 & 0.022 & 0.008 & 0.028 & 0.031 & 0.0031 & 0.0037 & 0.0012 & 0.002 & 0.0006 \\
\hline \multicolumn{5}{|c|}{ Not significant: } & \multirow{4}{*}{\multicolumn{3}{|c|}{$\begin{array}{l}\text { KnownConc }=0 \\
\text { REST }=0 \\
\text { D/S }=0\end{array}$}} & & & & & & & & & & & \\
\hline & Ta & Nb & $\mathrm{Cr}$ & Se & & & & & & & & & & & & & & \\
\hline & 0.0081 & 0.0023 & 0.0014 & 0.0013 & & & & & & & & & & & & & & \\
\hline & 0.0075 & 0.0013 & 0.0047 & 0.0009 & & & & ormal & & $\%: 99$ & & & & & & & & \\
\hline
\end{tabular}

The two main elements - the calotte and the neck guard - were joined using iron rivets (fig. 2: 3). They are still preserved on the inside (fig. 3: 4). The edge of the calotte and the neck guard was protected with a decorated binding made of bronze sheet (fig. 2: 3; 3: 3). Two triangular plaques were attached on the opposite sides of the calotte, probably using iron rivets; the cheek-pieces having a similar shape were attached to these plaques.

The decorated bronze studs having iron pins were affixed on the neck guard and the triangular plaques on the calotte; they were mould cast (for analogies regarding the manufacturing of hemispherical bronze studs with iron pins, decorated in the Plastic Style, see Berecki 2010; Ginoux et al. 2014; Müller 2011). These studs were decorated with triskele motifs in relief (fig. 2: 5-6; 3: 2). The ornamental band on the neck guard was also mould cast (fig. 2: 4-6; 3: 2, 3). It was decorated with a vegetal motif consisting of interlocked S-shaped details in relief (fig. 2: 6). These plastic ornaments imitate the filigree decoration using a technique which is frequently encountered on jewellery and costume accessories from the Carpathian Basin (see Szabó 1975).

Lastly, the calotte was probably decorated on the top with a conical plaque having a stud, similarly to other helmets of the same type. The ornamental element was not preserved and it's not mentioned in the original drawings.

Previous literature, from the first note until the articles published in the 1970s, mentions the existence of a "thin and crumpled" gold foil ("Das erhaltene Goldblatt ist sehr dünn und zerknittert...": Rusu 1969, 292), which would have covered the calotte. In the meantime, the gold foil disappeared. Its eventual metallographic analysis could have indicated the gold's provenance and perhaps also the area where the helmet was made. Gold was used to decorate other types of weaponry, for example a sword which was found in a LT grave from Aiud (Ferencz 2007, 38, Pl. 11; Rustoiu 2013, fig. 10: 1). In this case the scabbard decorated with a pair of dragons was also gilded, the foil being only partially preserved. At the same time, some gold jewellery, mostly rings, were also found in some LT B2 and LT C1 graves from Transylvania (Rustoiu 2016). [A.R.] 


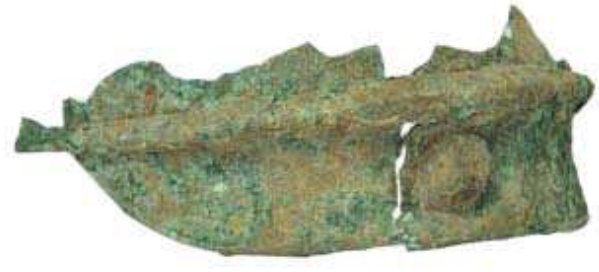

1

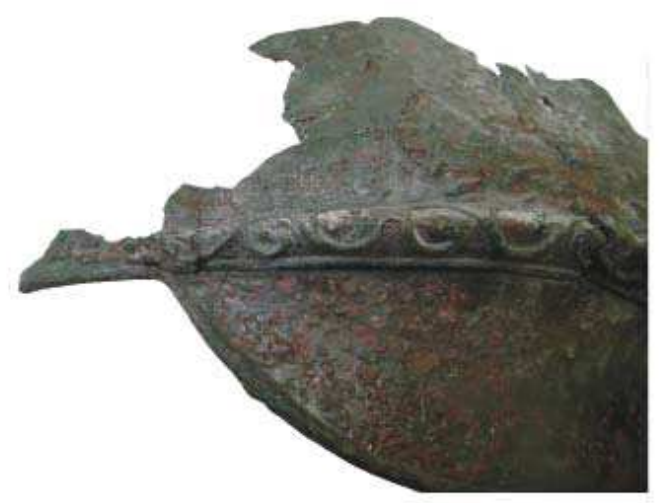

3
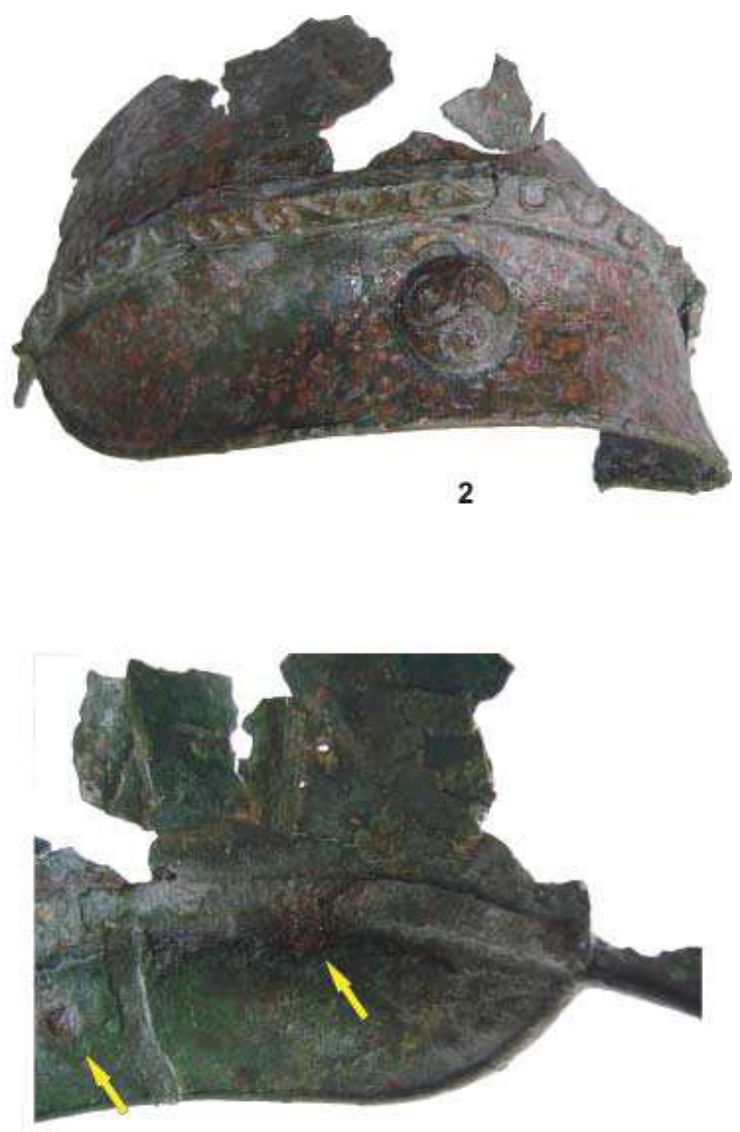

4

Fig. 3. Apahida, the bronze helmet. The neck guard and the fragmentary calotte before (1) and after restoration (2); 3-4 - Details of the inside and outside of neck guard; the arrows indicate traces of the iron rivets used to assemble the neckguard and the calotte, and the iron pin of the decorative knob. Photo by A. Rustoiu

\section{Typology, distribution, chronology}

The helmet from Apahida is the bronze variant of a type usually made of iron. This type of helmets was analysed by U. Schaaff, who called them iron helmets with a reinforced calotte and attached neck guard (ger. Eisenhelme mit verstärkter Kalotte und angesetztem Nackenschutz) (Schaaff 1974, 171-173; 1988, 294, 300, 301). Previously V. Megaw (1970, 133, 134, no. 211) observed the similarity of the helmet from Ciumeşti and the one from Batina, as well as the presence of this type among the weaponry depicted on the frieze from Pergamon.

The technology used to assemble the elements of the bronze helmet from Apahida is similar to that used in the manufacturing of iron helmets. Thus, it is quite sure that the craftsman who made the bronze helmet was also familiarized with the technology required for the manufacturing of the iron ones. Previous studies have shown that the metal working craftsmen of the Late Iron Age knew both the iron processing technologies and those used for copper alloys and other non-ferrous metals (Rustoiu 1996, 61-64).

The helmet from Apahida has the neck guard attached to the calotte with iron rivets, similarly to the iron examples. At the same time, the edge of the calotte and the neck guard is reinforced with a binding. The triangular plaques which are strengthening the calotte were also attached with three rivets each, probably made of iron. Lastly, the neck guard of some iron helmets has a horizontal nervure made in the repoussé technique. In the case of the helmet from Apahida, this decorative nervure was replaced by a band which was mould cast separately, before being attached to the neck guard. 

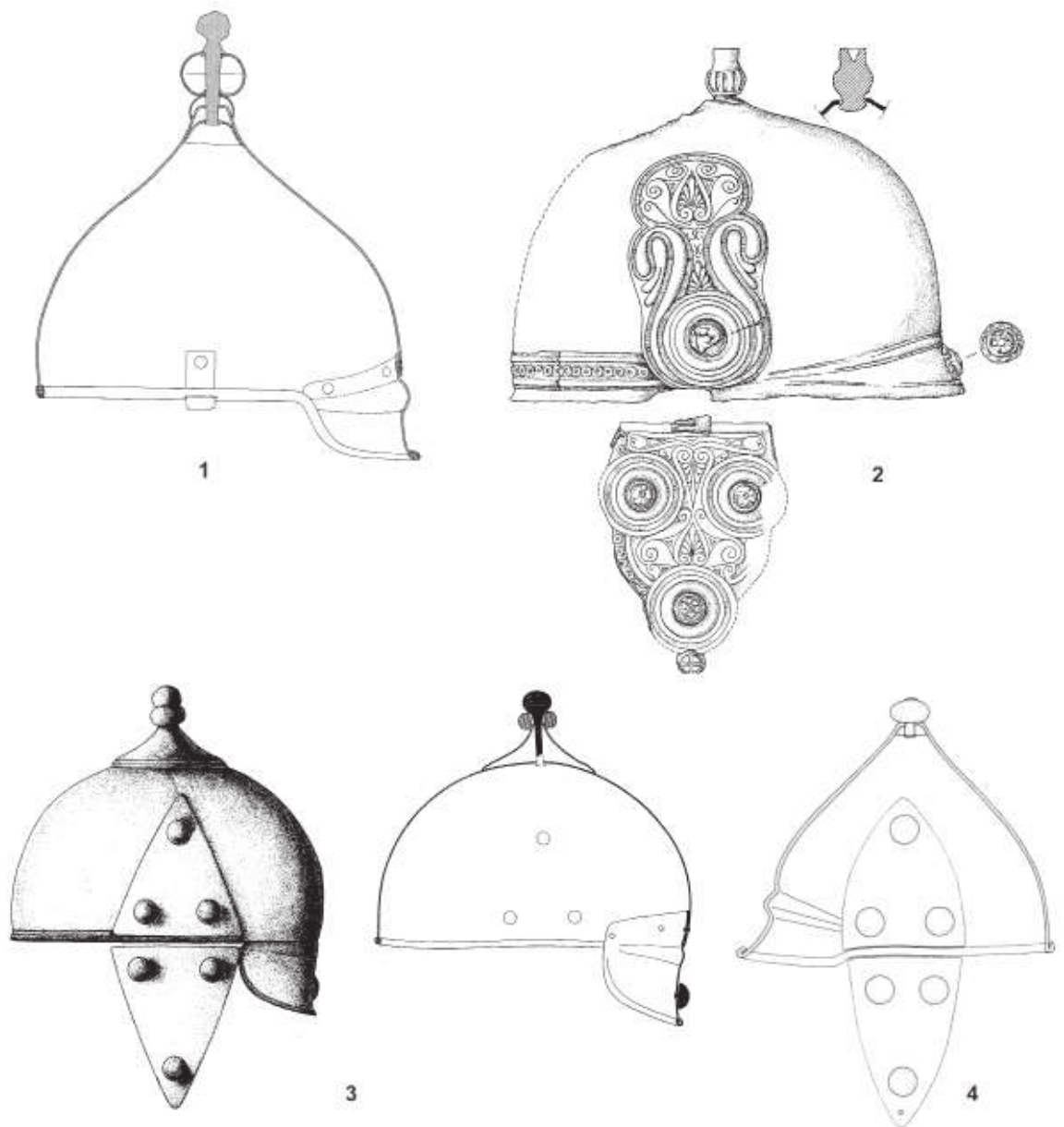

Fig. 4. The Celtic helmets: 1 - Iron helmet with a simple calotte and attached neck guard from Sanzeno (after Schaaff 1974); 2 - Iron helmet with bronze applied decorations on the calotte from grave no. 116 at Monte Bibele (after Vitali 1988); 3 - Helmet from Batina, reconstructed shape (after Schaaff 1988); 4 - Helmet from grave no. 143 at Ohrid (after Preložnik 2014)

Some details regarding the manufacturing of the helmets in question can also be observed on other earlier dated artefacts from the central Alpine area and Italy. Therefore, it might be presumed that the appearance of this type was inspired by these earlier helmets (see also Preložnik 2014, 112).

The helmets with a simple calotte from the Alpine area (Eisenhelme mit einfacher Kalotte und angesetztem Nackenschutz: Schaaff 1974, 150-171; 1988, 294, 297-300) have a similar neck guard which was attached to the calotte in the same manner (fig. 4: 1). Thus in the cases in which only the neck guard is discovered, their precise typological identification is more difficult. One example is the fragmentary helmet from Holiare (Benadik/Vlček/Ambros 1957, 91, fig. 27, Pl. 35), which was included by U. Schaaff $(1974,163,164)$ in the type with a simple calotte, whereas M. Guštin $(2011,123,124)$ suggested that it could belong to the type with a reinforced calotte, an identification which was further supported with more arguments by A. Preložnik $(2014,111)$. At the same time, some fragments of iron sheet from cremation grave no. 31 at Malé Kosihy could also belong to a helmet, though its precise typological identification is difficult (Bujna 1995, 25, Pl. 7: 10, 11).

Regarding the reinforcing of the calotte with two triangular plaques, this technological solution could have been inspired by the Italic iron helmets with bronze ornaments applied on the calotte (Lejars 2014, 409, 410; Mazzoli 2010; Schaaff 1974, 173-184; 1988, 302; Vitali 1988; etc). The latter have nearly oval vegetal ornaments made of bronze sheet on both sides of the calotte (fig. 4: 2). Their dimensions are similar to those of the triangular plaques on the 
helmets in question. At the same time, the decorative studs on the neck guard of some Italic helmets are also present on these artefacts.

In a recent study which has taken into consideration both the finds already discussed by U. Schaaff and those which were discovered later, A. Preložnik (2014, 111, 112, fig. 3) considered that the helmets with a reinforced calotte can be grouped in four types. The criteria used for this typology are diverse: the shape of the calotte and cheek-pieces, the presence or absence of the conical plaque on top of the calotte, the manufacturing techniques. However, it has to be underlined that only the technological details are relevant for a typology, since they suggest that the craftsmen who manufactured these helmets used different prototypes. At the same time, the morphological criteria more likely reflect aesthetic differences and regional variations of the primary type. Accordingly, the helmets with a reinforced calotte should be grouped in two variants.

The first variant, which could also be named Batina, includes helmets that have the neck guard attached to the calotte (fig. 4: 3). The helmet from Apahida belongs to this variant. This is not a separate type, as A. Preložnik $(2014,111)$ initially suggested. The manufacturing technique indicates quite clearly that the prototype of this variant was the helmet with a simple calotte.

The second variant, which could also be named Ohrid, includes helmets having the calotte and the neck guard made together of a single metal sheet (fig. 4: 4). Technologically, this variant seems to have been inspired by the Italic helmets with bronze ornaments applied on the calotte. The distribution areas of the two variants, as well as their chronology, provide important information regarding the manner in which they were created.

While discussing the distribution of this type of helmets, U. Schaaff observed that they belong to the eastern Celtic world. At that date, such iron helmets were only known in the Carpathian Basin: at Mihovo in Slovenia, Batina in Croatia and Ciumeşti in north-western Romania. A similar piece was also depicted on the "arms frieze" from the temple of Athena Nikephoros at Pergamon (Schaaff 1974, fig. 25; 1988, fig. 14). More than four decades later, the number of finds increased (still the helmets from Felsó Méra and Orosfaia, previously included in Rustoiu 2006 and Guštin 2011, do not belong to this type: Preložnik 2014, 111, 112). Many of the recently discovered pieces come from the Balkans (fig. 5; Guštin 2011, 123, 124, fig. 2; Rustoiu 2006, fig. 4; 2008, fig. 7). One helmet was found at Arkovna, in Bulgaria (Lazarov 2010, 105, fig. 4: 1) and another at Lin, in Albania (Ceka 1999, 329, no. 1, fig. 1). Two graves from the Ohrid - Gorna Porta cemetery contained one iron helmet with a reinforced calotte in their inventory (Guštin/Kuzman/Preložnik 2014; Preložnik 2014). Another bronze helmet was found in Asia Minor, being now part of a private collection (Preložnik 2014, 111, fig. 3: 9). These discoveries confirm once more the older opinion that the helmets of this type belong to the eastern Celtic world (fig. 5).

The helmets belonging to the first variant are usually found in the Carpathian Basin, but one similar example was also discovered in grave no. 138 at Ohrid. The helmets belonging to the second variants are only present in the Balkans and Asia Minor (fig. 5). These two distribution patterns more likely indicate the activity of different workshops in the respective distribution areas.

Regarding the chronology, a series of funerary discoveries allow the quite precise identification of the period in which these helmets were used. For example, the helmet from Mihovo was found together with a middle LT type sword (Schaaff 1974, 171). At the same time, the inventory of the grave from Batina is dated to the LT B2, thus being the earliest dated context containing a helmet of this type (Schaaff 1974, 190-192; Szabó/Petres 1992, 108, Pl. 99; Rustoiu 2006, 48). The grave with a helmet from Ciumeşti was dated to the end of the same LT phase or more likely to the LT C1 (Rustoiu 2006; 2008; 2012). The graves from Ohrid - Gorna Porta which contain such finds in their inventories were dated to the second half of the $3^{\text {rd }}$ century and the beginning of the $2^{\text {nd }}$ century BC, corresponding to the LT C1 in the 


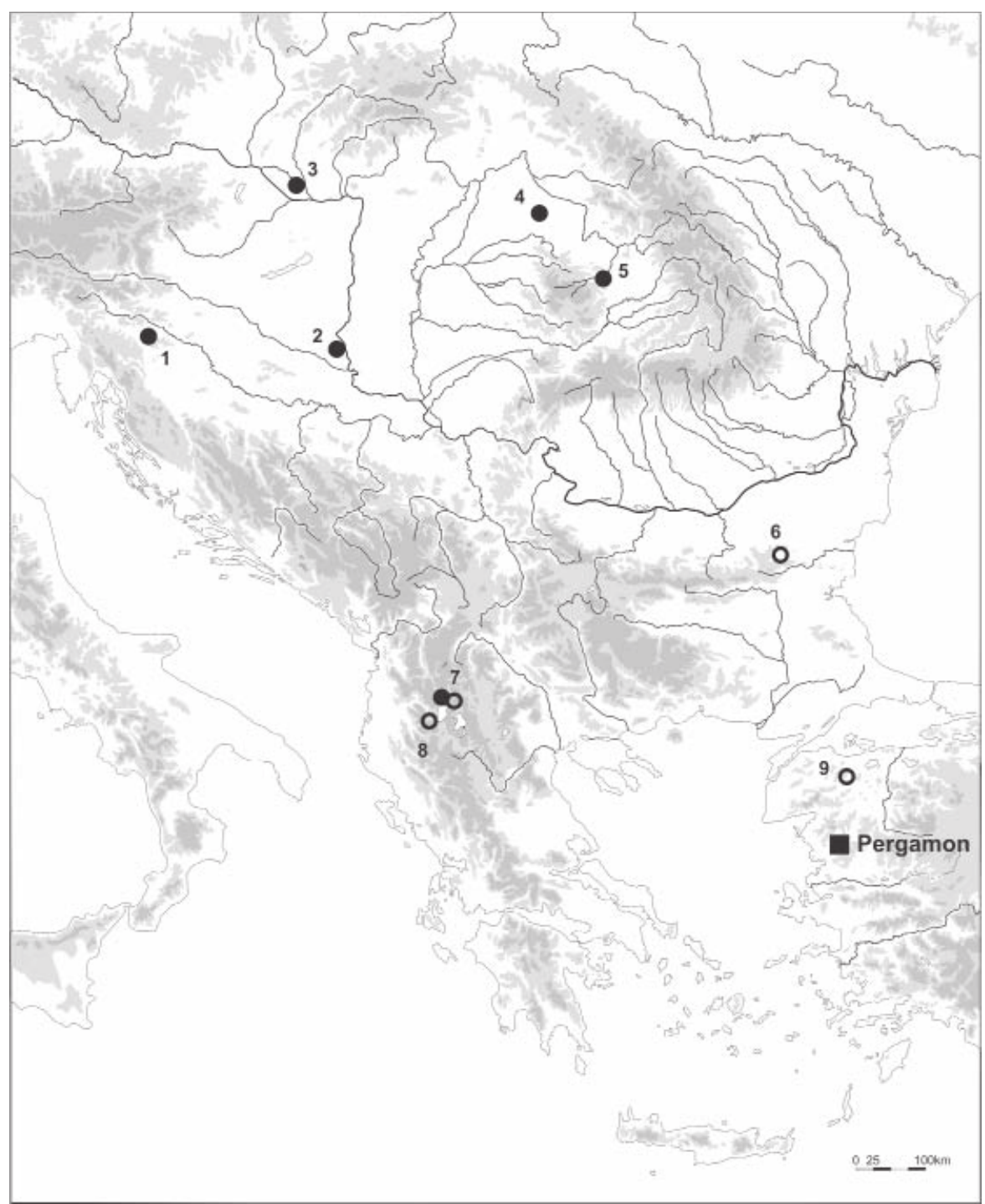

Fig. 5. Distribution of the iron and bronze helmets with a reinforced calotte.

Black dots - Batina variant; white dots - Ohrid variant; black square - figurative representations. 1 - Mihovo; 2 - Batina; 3 - Holiare; 4 - Ciumeşti; 5 - Apahida; 6 - Arkovna; 7 - Ohrid; 8 - Lin; 9 - Asia Minor (after Guštin 2011; Preložnik 2014; Rustoiu 2006)

Carpathian Basin (Guštin/Kuzman/Preložnik 2014). Lastly, the "arms frieze" from the temple of Athena Nikephoros at Pergamon was made in the first decades of the $2^{\text {nd }}$ century BC (Polito $1998,91-95)$. All of these discoveries indicate that the helmets in question were mainly used during the LT B2b and LT C1 phases, between the second third of the $3^{\text {rd }}$ century and the beginning of the $2^{\text {nd }}$ century $\mathrm{BC}$. They are succeeding the iron helmets with a simple calotte and the Italic ones with bronze ornaments applied on the calotte which more likely served as prototypes.

The inventory of the grave from Apahida which included the bronze helmet is offering too little information to allow a more precise dating. Aside from the decorated beaker, the remaining ceramic vessels are commonly found in Celtic cemeteries from the eastern Carpathian Basin (see Németi 1988). The carving knife (Hiebmesser) belongs to a common type (Zvonimirovo LT 12 type) in the Carpathian Basin, being dated to the LT B2 - LT C1 (Dizdar 2013, 123-130, map 11). Still, the shield boss provides a narrower dating; it belongs to the Rapin IIIa type which is primarily dated to the LT C1, the second half of the $3^{\text {rd }}$ century and the beginning of the $2^{\text {nd }}$ century BC (Rapin 1988, 80, fig. 39). Accordingly, the bronze helmet can also be dated to the same period of time. [A.R.] 


\section{Conclusion}

The iron helmets with a reinforced calotte and attached neck guard from the Carpathian Basin appeared in the second quarter - second half of the $3^{\text {rd }}$ century BC. They are a local version of some helmets used in the Alpine area and Italy at the end of the $4^{\text {th }}$ century and the beginning of the $3^{\text {rd }}$ century BC. The helmets having a simple calotte are also encountered eastward during the same period, more likely as a result of Celtic "colonization" (see Rustoiu 2014). This is the case of the helmet from "Silivaş" in Transylvania (fig. 6: 1, 2) (Rustoiu 2013, with previous bibliography). As demonstrated above, the helmet from Apahida is a bronze adaptation of the iron helmets with a reinforced calotte and attached neck guard. The helmets of this kind belong to a distinct variant that can be called Batina.

Similar artefacts also reached the Balkans, as one of the finds from Ohrid is indicating. This is more likely the result of the southward movement of mercenary troops recruited from the Carpathian Basin. After the invasions in the Balkans and Greece in 280 - 277 BC and until the beginning of the $2^{\text {nd }}$ century $B C$, Celtic mercenaries were frequently involved in numerous military conflicts caused by the political ambitions of various Hellenistic rulers. They were encountered in Greece, Asia Minor and the Levant, but also in the Ptolemaic Egypt (Griffith 1968; Rustoiu 2006, 53-66; 2008, 37-63; Szabó 1991). These conditions facilitated the circulation of various elements of the LT material culture across wider areas.

Aside from these helmets which were specific to the Carpathian Basin, other examples with different technological characteristics appeared in the Balkans and Asia Minor. They belong to the so-called Ohrid variant whose calotte and neck guard were made together of a single metal sheet. These helmets were dated to the second half of the $3^{\text {rd }}$ century and the beginning of the $2^{\text {nd }}$ century BC.

The typological and technological differences, as well as those regarding the distribution and chronology, indicate that craftsmen originating from different areas contributed to the appearance of these variants. Thus the helmets belonging to the Batina variant were created by craftsmen who were familiar with the technologies used in the Alpine area and who probably arrived in the Carpathian Basin during the eastward movement of some "colonist" groups. The circulation of some helmets of this type in the Balkans and the eastern Mediterranean contributed to the rising interest of the elites from these regions for such goods. Still, these were made by craftsmen who were familiarized with the technology of manufacturing Italic helmets. As a consequence, in spite of a nearly similar shape, the two variants differ from the technological point of view.

These observations are also raising the question of craftsmen's mobility. This phenomenon can be better understood in connection with the need of the elites to acquire the so-called "desirable goods". These are "goods [...] perceived as having a higher social, political or/and economic relevance in a given society" (Egri 2014, 233). In this context, the elites' mobility often determined the artisans' mobility, especially of those who were "attached" (for the distinction between the "attached" and the "independent" specialists see Brumfiel/Earle 1987, 5, 6; Earle 1981; Costin 1991, 5, fig. 1: 1; 2005, 1069-1071; Egri 2014; Nørgaard 2014, 39, 40 etc). One relevant example is provided by a discovery from north-eastern France. In this case, the recent metallographic analysis of some bronze fittings decorated in the Plastic Style which were applied on a wooden shield from the cemetery at Plessis-Gassot, dated to the first half of the $3^{\text {rd }}$ century BC, indicated that the manufacturing technique is similar to that of some artefacts from the Carpathian Basin. It has been therefore concluded that the respective technological knowledge circulated from the east to the west due to a mobile artisan working for the local warlike elites, who were also highly mobile during this period (Ginoux et al. 2014).

Returning to the helmets in question, the craftsmen who created the pieces belonging to the Ohrid variant could have originated from Italy, crossing the Adriatic together with some mercenary groups that fought in the Balkans during the same period in which these artefacts were produced. Very relevant in this case is the peregrination of a Celtic mercenary group, 

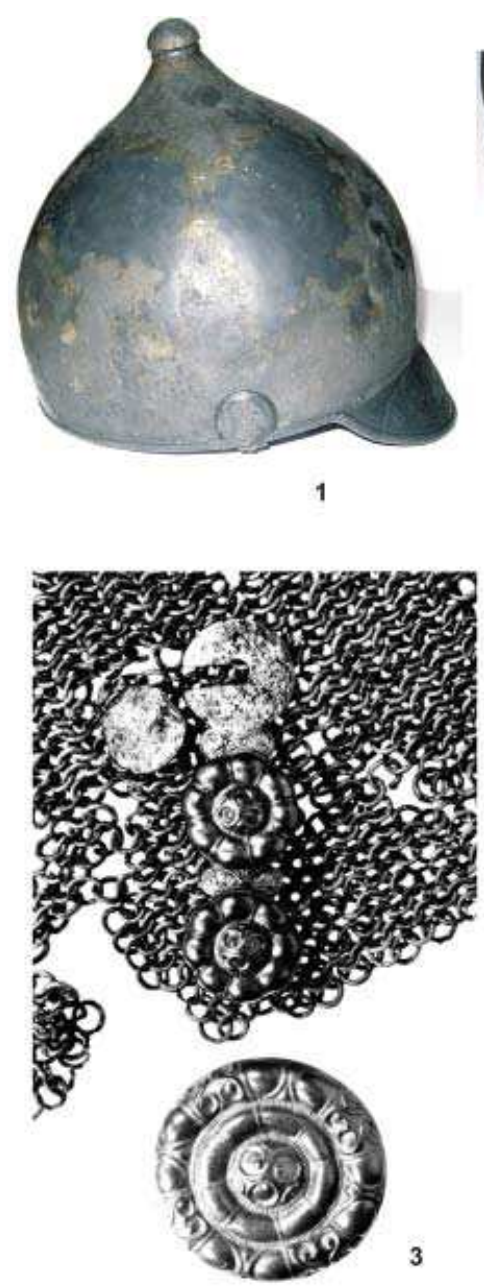

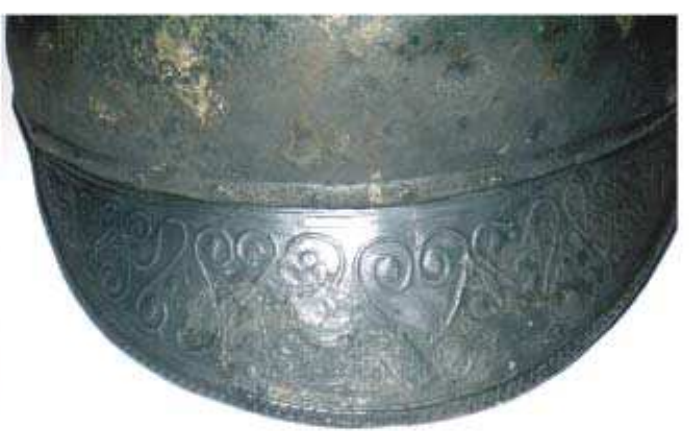

2

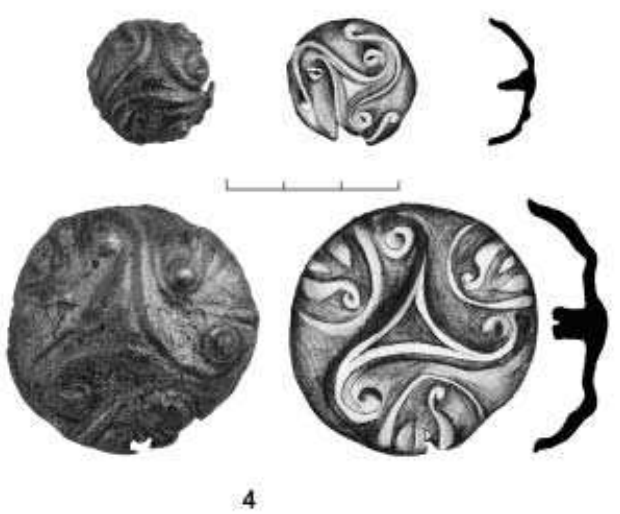

4

Fig. 6. The Celtic helmets. 1-2 - Iron helmet with a simple calotte and attached neck guard from "Silivaş" (photo M. Egri); 3 - Details of the decorated bronze discs on the iron chain-mail from Ciumeşti (after Rusu 1969); 4 - Decorated bronze discs having iron pins from Târgu Mureş (after Berecki 2010)

probably from northern Italy (Rustoiu 2006, 56). Polybius (II, 5; II, 7) writes that they were initially banished by their own compatriots and were then enrolled by Carthage during the first Punic war. Cantoned in Sicily (over 3000 people), the Celts were guarding Acragas, when a conflict with the generals had started over payment and as a result, they plundered the town. The mercenaries were then sent to Eryx, but they attempted to hand over the garrison and town to the Romans besieging them. Their action failed and some of the mercenaries (around 1000 people, because the other 2000 were involved in the "mercenaries' riot" in northern Africa - see Polybius I, 77) deserted to the Romans. However, the unruly Celts plundered a temple and became too troublesome for their new masters, so Roman authorities sent them to Epirus, where they (about 800 people) were tasked with guarding Phoenice. Even here, they were unwilling to fulfil the "contract" and handed over the town to the Illyrian queen Teuta for a large sum of money. Summarising this peregrination, it seems that the entire Celtic contingent was probably recruited initially in the Syracuse emporium at Ancona (a practice which was used for more than a century: Kruta 2000, 253), and then through the Sicilians they were hired by Carthage. After their desertion to the Romans, the Celtic mercenaries were sent over to Epirus more likely as part of a diplomatic agreement - an ill-fated choice of employees. 

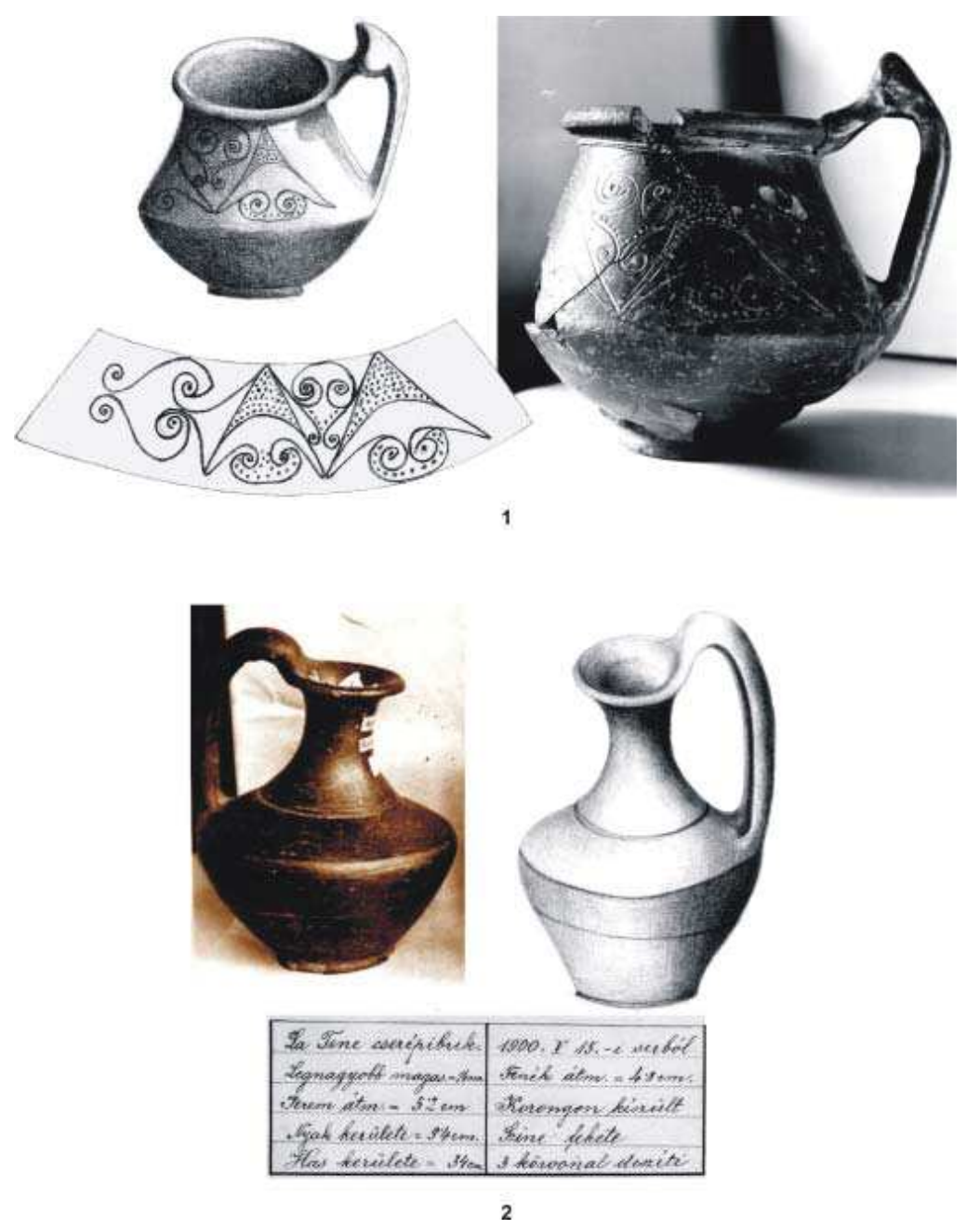

Fig. 7. 1 - Apahida. Decorated beaker from the grave with a helmet; 2 - Beaker initially ascribed to the grave with a helmet but discovered in a different funerary context.

Photo and drawings from Orosz archive

It can be therefore observed that even if the helmets from the Ohrid graves were taken over and used by the indigenous warriors (according to Guštin/Kuzman/Preložnik 2014), their presence was more likely a consequence of the contacts established between their elites and the Celtic mercenaries who reached the region in question.

Several studies have shown that in general the helmets are also perceived as symbols of status among different societies. In the case of the helmet from Apahida, this symbolic role is also underlined by its gilded ornamentation, among other things. It has already been demonstrated that in the case of some types of jewellery dated to the LT B2b-LT C1, like the saddle-shaped rings, the ratio between those made of gold, silver and bronze is 1:2:4 (Rustoiu 2016). This ratio is relevant for the manner in which precious metals were used among the communities from the Carpathian Basin, pointing to a free distribution which was only regulated by the communal social structure and relations, as well as the economic power of each group. The ratio between the artefacts made of precious metals and those made of common metals is also reflecting the social competition among the members of elite groups, on one hand, and between them and other groups within these communities, on the other hand. The gilding of the bronze helmet from Apahida indicates that the owner was more likely a member of the community's elite, having access to important economic resources.

This social affiliation is also suggested by the helmet's decoration. The triskele motif on the studs affixed on the calotte's triangular plaques and the neck guard, made in relief using 
the pseudo-filigree, is frequently encountered on weaponry and other elements of military equipment (see numerous examples in Szabó/Petres 1992), for example on the bronze discs of the chain-mail from Ciumeşti (fig. 6: 3) (Rusu 1969; etc) or on the recently published pieces from Târgu Mureş (fig. 6: 4) (Berecki 2010). At the same time, the vegetal motif decorating the neck guard is made in the same technique, resembling in a simplified manner the earlier dated flowing, curvilinear ornaments, or the various types of tendrils decorating metal artefacts from Central and Western Europe (Megaw 2011). Unlike the ornaments on the helmet, the incised decoration of the beaker coming from the same grave provides a relevant example of adopting and freely transforming motifs specific to the Swords Style on ceramics (fig. 7: 1) (Szabó/Petres 1992, 53, 54). The motifs in question are also important visual elements that defined the symbolic language of the elites from the region in question.

Lastly, the complete panoply of weapons with whom the deceased was buried is also indicating that he was a member of the warrior social group within the community. In the case of the cemetery from Apahida, around $15 \%$ of the total number of graves whose inventory was reconstituted belonged to the warriors (Rustoiu 2006, 61, tab. 3), a percentage that is close to the average percentage of $18 \%$ which was proposed by J. Bujna many years ago for the entire Carpathian Basin (Bujna 1982,360). Both the inventory of the grave with a helmet, as well as the percentage of grave containing weapons from the entire cemetery underline the important social position of the warrior from Apahida within the local community. [A.R.]

\section{Acknowledgments}

The authors warmly thank Assoc. Prof. Dr. Simona Varvara (“1 Decembrie 1918” University of Alba Iulia, Dept. of Exact Sciences and Environmental Engineering) for the XRF analysis of the fragments from the helmet's calotte, Dan Anghel (National Museum of Unification Alba Iulia) for the restoration, and Narcisa Şugar for drawings.

\section{BIBLIOGRAPHY}

ArchÉrt 1901 - La Tène sírmező Erdélyben. Archaeologiai Értesítő 21, 1901, 288.

Bajusz 2005 - I. Bajusz (ed.): Téglás István Jegyzetei. Régészeti feljegyzések, I/1. Kolozsvár 2005.

Benadik/Vlček/Ambros 1957 - B. Benadik/E. Vlček/C. Ambros: Keltische Gräberfelder der Südwestslowakei. Bratislava 1957.

Berecki 2006 - S. Berecki: Rite and Ritual of the Celts from Transylvania. In: V. Sîrbu/D. L. Vaida (eds.): Thracians and Celts. Proceedings of the International Colloquium from Bistrița, 18-20 mai, 2006. Cluj-Napoca 2006, 51-76.

Berecki 2010 - S. Berecki: Two La Tène Bronze Discs from Târgu Mureş, Transylvania. Marisia 30, 2010, 69-75.

Berecki 2015 - S. Berecki: Iron Age settlement patterns and funerary landscapes in Transylvania $\left(4^{\text {th }}-2^{\text {nd }}\right.$ centuries BC), Catalogi Mvsei Marisiensis, Series Archaeologica 2. Târgu Mureş 2015.

Berecki 2017 - S. Berecki: Az Orosz gyújtemény - Colecția Orosz. In: S. Berecki/E. Horti/K. Kacsó/D. Nyulas: Orosz Endre régészeti gyújteménye - Colecția arheologică a lui Endre Orosz, Catalogi Mvsei Marisiensis, Series Archaeologica 3. Cluj-Napoca 2017, 103-108.

Berecki et al. 2017 - S. Berecki et al.: Orosz Endre régészeti gyújteménye - Colecția arheologică a lui Endre Orosz, Catalogi Mvsei Marisiensis, Series Archaeologica 3. Cluj-Napoca 2017.

Brumfiel/Earle 1987 - E. M. Brumfiel/T. K. Earle: Specialization, exchange, and complex societies: An introduction. In: E. M. Brumfiel/T. K. Earle (eds.): Specialization, Exchange, and Complex Societies. Cambridge 1987, 1-9.

Bujna 1982 - J. Bujna: Spiegelung der Sozialstruktur auf latènezeitlichen Gräberfeldern im Karpatenbecken. Památky archeologické 73, 1982, 312-431. 
Bujna 1995 - J. Bujna: Malé Kosihy. Latènezeitliches Gräberfeld. Katalog. Archaeologica Slovaca Monographiae 7. Nitra 1995.

Ceka 1999 - N. Ceka: Les Celtes en Illyrie méridionale et en Épire. In: P. Cabanes (ed.): L’Illyrie méridionale et l'Épire dans l'Antiquité - III. Paris 1999, 327-333.

Costin 1991 - C. L. Costin: Craft specialization: issues in defining, documenting, and explaining the organization of production. Archaeological Method and Theory 3, 1991, 1-56.

Costin 2005 - C. L. Costin: Craft production. In: H. D. G. Maschner (ed.): Handbook of Methods in Archaeology. Walnut Creek 2005, 1032-1105.

Crişan 1971 - I. H. Crişan: Necropola celtică de la Apahida. Acta Musei Napocensis 8, 1971, 37-70.

Dizdar 2013 - M. Dizdar: Zvonimirovo-Veliko polje. A cemetery of the La Tène culture. Zagreb 2013.

Earle 1981 - T. K. Earle: Comment on P. Rice, Evolution of specialized pottery production: a trial model. Current Anthropology 22, 1981, 230, 231.

Egri 2014 - M. Egri: Desirable goods in the Late Iron Age - the craftsman's perspective. In: S. Berecki (ed.): Iron Age Crafts and Craftsmen in the Carpathian Basin. Proceedings of the International Colloquium from Târgu Mureş, 11-13 October 2013. Bibliotheca Musei Marisiensis, Series Archaeologica 7. Târgu Mureş 2014, 233-248.

Ferencz 2007 - I. V. Ferencz: Celții pe Mureşul mijlociu. La Tène-ul timpuriu şi mijlociu în bazinul mijlociu al Mureşului (sec. IV-II î. Chr.). Sibiu 2007.

Ferencz 2017 - I. V. Ferencz: Muzeul din Deva. Arc peste timp. Deva 2017.

Ginoux et al. 2014 - N. Ginoux et al.: Metal craft and warrior elites in the third century BC: New sights from the Carpathian Basin to Gaul. In: S. Berecki (ed.): Iron Age Crafts and Craftsmen in the Carpathian Basin. Proceedings of the International Colloquium from Târgu Mureş, 11-13 October 2013. Bibliotheca Musei Marisiensis, Series Archaeologica 7. Târgu Mureş 2014, 9-18.

Griffith 1968 - G. T. Griffith: The mercenaries of the Hellenistic World. Groningen 1968.

Guštin 2011 - M. Guštin: On the Celtic tribe of Taursici. Local identity and regional contacts in the ancient world. In: M. Guštin/M. Jevtić (eds.): The Eastern Celts. The communities between the Alps and the Black Sea. Koper-Beograd 2011, 119-128.

Guštin/Kuzman/Preložnik 2014 - M. Guštin/P. Kuzman/A. Preložnik: Celtic helmets from Hellenistic necropolises at Ohrid. In: M. Guštin/W. David (eds.): The clash of cultures? The Celts and the Macedonian world. Manching 2014, 85-106, in print.

https://www.academia.edu/33003333/GU\% C5\%A0TIN_M._DAVID_W._eds._The_Clash_of_ Cultures_The_Celts_and_the_Macedonian_World_Manching_2014_in_print_

Date of citation June 28, 2018.

Hunyadi 1942 - I. Hunyady: Die Kelten im Karpatenbecken. Tafelband, Dissertationes Pannoniae, ser. 2. Budapest 1942.

Kovács 1911 - I. Kovács: Az apahidai őskoritelepés La Tène temető. Dolgozatok az Erdélyi Nemzeti Múzeum Érem- és Régiségtárából 2, 1911, 1-56.

Kruta 2000 - V. Kruta: Les Celtes. Histoire et dictionaire. Des origines à la romanisation et aux christianisme. Paris 2000.

Lazarov 2010 - L. Lazarov: The Celtic Tylite State in the time of Cavaros. In: L. F. Vagalinski (ed.): In search of Celtic Tylis in Trace (III c. B.C.). Proceedings of the Interdisciplinary Colloquium arranged by the Archaeological Institute and Museum at Sofia and the Welsh Department, Aberystwyth University held at the National Archaeological Institute and Museum in Sofia, 8 May 2010. Sofia 2010, 97-114.

Lejars 2014 - T. Lejars: L'armement des Celtes d'Italie. In: Ph. Barral et al. (eds.): Les Celtes et le Nord de l'Italie (Premier et Second Âges du fer), Actes du XXXVIe colloque international de l'AFEAF (Vérone, 17-20 mai 2012) 401. 36e supplément à la Revue Archéologique de l'Est 2014, 401-434. 
Mazzoli 2010 - M. Mazzoli: Was macht ein keltischer Prunkhelm in Apulien? Der Helm von Canosa. In: M. Schönfelder (ed.): Kelten! Kelten? Keltische Spuren in Italien, Begleitbuch zur Ausstellung im Römisch-Germanischen Zentralmuseum, Mai-August 2010. Mainz 2010, 30-33.

Megaw 1970 - J. V. S. Megaw: Art of the European Iron Age. A study of the elusive image. Bath 1970.

Megaw 2011 - J. V. S. Megaw: The iron armring with vegetal decoration. In: A. Rustoiu/J. V. S. Megaw: A foreign flowering in Transylvania: the Vegetal style armring from FântâneleDealul Popii, jud. Bistrița-Năsăud, grave 62. In: D. Măgureanu/D. Măndescu/S. Matei (eds.): Archaeology: Making of and Practice. Studies in Honour of Mircea Babeş at his $70^{\text {th }}$ Anniversary. Piteşti 2011, 229-233.

Mödlinger et al. 2013 - M. Mödlinger et al.: Archaeometallurgical characterization of the earliest European metal helmets. Materials Characterization 79, 2013, 22-36.

Müller 2011 - F. Müller: Ein latènezeitlicher Zierknopf im plastischen Stil. Archäologisches Korrespondenzblatt 41, 2011, 521-529.

Németi 1988 - I. Németi: Unele aspecte ale evoluției ceramicii din a doua epocă a fierului în nord-vestul României (Latène B-C). Studii şi cercetări de istorie veche şi arheologie 39/2, 1988, 87-111.

Nørgaard 2014 - H. W. Nørgaard: Are valued craftsmen as important as prestige goods? Ideas about itinerant craftsmanship in the Nordic Bronze Age. In: S. Reiter et al. (eds.): Rooted in Movement. Aspects of Mobility in Bronze Age Europe. Højbjerg 2014, 37-52.

Orosz 1908 - E. Orosz: Az apahidai „Rétiőstelep” (Kolozs m.). Archaeologiai Értesítő 28, 1908, 172-179.

Polito 1998 - E. Polito: Fulgentibus armis. Introduzione allo studio dei fregi d'armi antichi. Roma 1998.

Preložnik 2014 - A. Preložnik: Eastern Celtic helmets with a reinforced calotte - between north and south. In: M. Guštin/W. David (eds.): The clash of cultures? The Celts and the Macedonian world. Manching 2014, 107-116 (in print).

https://www.academia.edu/33003333/GU\% C5\% A0TIN_M._DAVID_W._eds._The_Clash_of_ Cultures_The_Celts_and_the_Macedonian_World_Manching_2014_in_print_

Date of citation June 28, 2018.

Rapin 1988 - A. Rapin: Boucliers et lances. In: J.-L. Brunaux/ A. Rapin: Gournay II. Boucliers et lances - Dépôts et trophées. Paris 1988, 7-142.

Rustoiu 1996 - A. Rustoiu: Metalurgia bronzului la daci (sec. II 1̂. Chr. - sec. I d. Chr.). Tehnici, ateliere şi produse de bronz, Bibliotheca Thracologica 15. Bucureşti 1996.

Rustoiu 2006 - A. Rustoiu: A Journey to Mediterranean. Peregrinations of a Celtic Warrior from Transylvania. Studia Universitatis „Babeş-Bolyai”. Historia 51, Special Issues: Focusing on Iron Age Élites, 2006, 42-85.

Rustoiu 2008 - A. Rustoiu: Războinici şi societate în aria celtică transilvăneană. Studii pe marginea mormântului cu coif de la Ciumeşti. Cluj-Napoca 2008.

Rustoiu 2012 - A. Rustoiu: Commentaria Archaeologica et Historica (I). 1. The grave with a helmet from Ciumeşti - 50 years from its discovery. Comments on the greaves. 2 . The Padea-Panagjurski kolonii group in Transylvania. Old and new discoveries. Ephemeris Napocensis 22, 2012, 159-183.

Rustoiu 2013 - A. Rustoiu: Wandering warriors. The Celtic grave from "Silivaş" (Transylvania) and its story. Terra Sebus 5, 2013, 211-226.

Rustoiu 2014 - A. Rustoiu: Indigenous and colonist communities in the eastern Carpathian Basin at the beginning of the Late Iron Age. The genesis of an eastern Celtic World. In: C. N. Popa/S. Stoddart (eds.): Fingerprinting the Iron Age. Approaches to Identity in the European Iron Age. Integrating South-Eastern Europe into the Debate. Oxford 2014, 142-156. 
Rustoiu 2016 - A. Rustoiu: Lords and ladies of the rings. Saddle-shaped rings from the Carpathian Basin. Archeologické rozhledy 68, 2016, 333-362.

Rusu 1969 - M. Rusu: Das keltische Fürstengrab von Ciumeşti in Rumänien. Bericht der Römisch-germanischen Kommission 50, 1969, 267-300.

Rusu/Bandula 1970 - M. Rusu/O. Bandula: Mormântul unei căpetenii celtice de la Ciumeşti.

Baia Mare 1970.

Schaaff 1974 - U. Schaaff: Keltische Eisenhelme aus vorrömischer Zeit. Jahrbuch des Römisch-

Germanisches Zentralmuseum Mainz 21, 1974, 149-204.

Schaaff 1988 - U. Schaaff: Keltische Helme. In: Antike Helme. Mainz 1988, 293-317.

Szabó 1975 - M. Szabó: Sur la question de filigrane dans l'art des celtes orientaux. In: J. Fitz

(ed.): The Celts in Central Europe. Székesfehérvár 1975, 147-165.

Szabó 1991 - M. Szabó: Il mercenariato. In: I Celti. Milano 1991, 333-336.

Szabó/Petres 1992 - M. Szabó/E. F. Petres: Decorated weapons of the La Tène Iron Age in the

Carpathian Basin. Budapest 1992.

Vincze 2014 - Z. Vincze: A kolozsvári régészeti iskola a Pósta Béla-korszakban (1899-1919)

Kolozsvár 2014.

Vitali 1988 - D. Vitali: Elmi di ferro et cinturoni a catena nuove proposte per l'archeologia

dei Celti in Italia. Jahrbuch des Römisch-Germanisches Zentralmuseum Mainz 35, 1, 1988,

239-284.

Zirra 1976 - V. Zirra: La nécropole La Tène d'Apahida, Nouvelles considerations. Dacia N.S.

20, 1976, 129-165.

\section{RESUMÉ}

\section{Bronzová prilba z neskorej doby železnej z Apahidy (Transylvánia)}

Bronzová prilba objavená v laténskom hrobe v Apahide v roku 1900 je dobre známa v odbornej literatúre. Nález sa dlhodobo nachádzal v súkromnej zbierke a len nedávno bol darovaný do krajského múzea v Târgu Mureş. Pri tejto príležitosti boli identifikované zatial' nepublikované fragmenty, ktoré umožňujú dôkladnejšiu typologickú identifikáciu.

Prilba z Apahidy opätovne otvára debatu o typológii a chronológii analogických nálezov z Karpatskej kotliny a umožňuje detailnejší pohl'ad na elitu rurálnych komunít v sledovanom regióne v období včasnej a strednej doby laténskej. Nález predstavuje bronzový variant typu tradične vyrábaného zo železa. Je preto nepochybné, že jeho výrobca poznal technológiu potrebnú na výrobu železných variantov. Prilby so zosilnenou kalotou sa dajú zaradit' do dvoch variantov: batinský variant predstavujú prilby, ktoré majú samostatne pripevnený chránič krku (ako prilba z Apahidy). Ochridský variant reprezentujú prilby, ktoré majú kalotu a chránič krku kovaný z jedného plechu. Železné prilby typu Batina sa v Karpatskej kotline objavujú v druhej štvrtine - druhej polovici3. storočia pred Kr.Sú lokálnym variantom niektorých prilieb používaných v alpskom regióne a v Taliansku na konci 4. storočia a začiatkom 3. storočia pred Kr. Ochridské varianty sú datované do druhej polovice 3. storočia až začiatku 2. storočia pred Kr. Technika výroby jednotlivých variantov, ako aj ich rozšírenie a datovanie ponúkajú relevantné informácie o ich pôvode. Prvý variant bol vytvorený remeselníkmi z Karpatskej kotliny, druhý variant vyrobili na Balkáne s pomocou talianskych kováčov.

Prilby patriace k jednotlivým variantom sa stali dôležitými vizuálnymi prejavmi sociálneho postavenia ich majitel'ov. Pozlátenie bronzovej prilby z Apahidy poukazuje na vyššie sociálne postavenie jej majitel'a, ktorý mal prístup k dôležitým ekonomickým zdrojom. Sociálne postavenie potvrdzuje aj zdobenie prilby. Motív triskelionu na čapoch, pripevnených na trojuholníkové plakety kaloty a chránič krku, bol reliéfne upravený technikou pseudofiligránu, ktorá sa často aplikuje na zbraniach a iných prvkoch vojenskej výzbroje. Vegetatívny motív nachádzajúci sa na chrániči krku je vytvorený rovnakou technikou, zobrazujúci v jednoduchšom prevedení skoršie datované ornamenty, vlnené línie a rôzne typy úponiek zdobiace kovové predmety zo strednej a západnej Európy. Opísané motívy sú dôležitým vizuálnym prvkom, 
ktorý definoval symbolický prejav elít v sledovanom regióne. Nakoniec aj celá zbroj, s ktorou bol mŕtvy pochovaný, poukazuje na skutočnost', že išlo o člena vyššej sociálnej skupiny patriacej bojovníkom. V prípade pohrebiska v Apahide, približne 15 \% všetkých hrobov, ktorých inventár bol rekonštruovaný, patrilo bojovníkom. Ide o počet vel'mi blízky priemeru (18 \%), ktorý bol pred mnohými rokmi stanovený J. Bujnom.

\section{Obrazová príloha}

Obr. 1. Apahida, inventár hrobu objaveného 27. marca 1900. 1 - železný nôž (zdroj snímky a kresby: archív Orosz); 2 - železná špička kopije (zdroj kresby: archív Orosz); 3 - štítová puklica (snímka S. Berecki; zdroj kresby: archív Orosz); 4-8 - hlinené nádoby. Snímka S. Berecki.

Obr. 2. Apahida, bronzová prilba. 1 - zdroj kresieb: archív Orosz; 2 - chýbajúce fragmenty z prilby (podl'a Crişan 1971); 3-7 - zachované fragmenty a ideálna rekonštrukcia prilby. Kresba N. Şugar.

Obr. 3. Apahida, bronzová prilba. Chránič krku a fragmenty kaloty pred reštaurovaním (1) a po reštaurovaní (2); 3-4 - detaily vonkajšej a vnútornej strany chrániča krku; šipky ukazujú miesta železných nitov používaných na spojenie chrániča krku a kaloty a železného kolíka na pripevnenie ozdobného gombíka. Snímka S. Berecki.

Obr. 4. Keltské prilby. 1 - železná prilba s jednoduchou kalotou a pripevneným chráničom krku zo Sanzena (podl'a Schaaff 1974); 2 - železná prilba s bronzovou výzdobou na kalote z hrobu 116 v Monte Bibele (podl'a Vitali 1988); 3 - prilba z Batiny, rekonštrukcia tvaru (podl'a Schaaff 1988); 4 - prilba z hrobu 143 z Ochridu (podl'a Preložnik 2014).

Obr. 5. Rozšírenie železných a bronzových prilieb so zosilnenou kalotou. Čierne krúžky - variant Batina; biele krúžky - variant Ohrid; čierne štvorce - obrazové znázornenia. 1 Mihovo; 2 - Batina; 3 - Holiare; 4 - Ciumeşti; 5 - Apahida; 6 - Arkovna; 7 - Ohrid; 8 - Lin; 9 - Asia Minor (podl'a Guštin 2011; Preložnik 2014; Rustoiu 2006).

Obr. 6. Keltské prilby. 1-2 - Železné prilby s jednoduchou kalotou a pripevneným chráničom krku zo "Silivaşu”. Snímka M. Egri; 3 - Detail zdobeného bronzového kotúča na krúžkovom pancieri z Ciumeşti (podĺa Rusu 1969); 4 - Zdobený bronzový kotúč so železnými zachycovačmi z Târgu Mureș (podl'a Berecki 2010).

Obr. 7. 1 - Apahida, zdobený džbán z hrobu s prilbou; 2 - Džbán pôvodne priradený hrobu s prilbou, ale objavený v odlišnom hrobovom kontexte. Zdroj snímky a kresby: archív Orosz.

Tabela 1. XRF analýza fragmentu kaloty. Autor: Simona Varvara.

Dr. Habil. Aurel Rustoiu

Institutul de Arheologie şi Istoria Artei

Str. M. Kogălniceanu 12-14, 400084 Cluj-Napoca, Romania

aurelrustoiu@yahoo.com

Dr. Sándor Berecki

Muzeul Județean Mureş

CP 85, Str. Mărăşti 8A, 540328 Târgu Mureş, Romania

sberecki@yahoo.com 